\title{
Antibacterial Efficiency of Fabaceae Plants of a Tropical Freshwater Lake
}

\author{
K. Nagarajan, M. Saravanararaja* and P. S. Aruna Devi
}

PG and Research Department of Zoology, Sri Vasavi College, Erode - 638 316, India; sararajabio@rediffmail.com

\begin{abstract}
Obtaining the plant drugs for the production of commercial products is the recent research scenario. But still, the role of a plant species in its ecosystem is not much explored. The present study intended to find antibacterial activity of Fabaceae plant species in a tropical freshwater lake against isolated indigenous bacterial species. Results revealed that the fabaceae plants Abrus precatorus, Acacia nilotica, Cajanas cajan, Cassia auriculata, Clitoria ternatia, Crotalaria vergosa, Crotia ternatia, Mimosa pudica, Pongamia pinnata, Sesbania grandiflora, Tephrosia purpuria and Vigna mungo of Vellode lake have potential antibacterial activity against indigenous bacterial isolates from soil and water samples.
\end{abstract}

Keywords: Fabaceae Plants, Indigenous Bacteria, Tropical Freshwater Lake

\section{Introduction}

India is proud to be rich in biodiversity and possess about $8 \%$ of estimated biodiversity of the world with around 12600 species [1]. There are about 400 families of the plants in the world of which 315 are represented in India [2]. According to World Health Organization (WHO), plants are best sources to obtain variety of drugs to treat various diseases [3]. Plants are widely used in human therapy, veterinary, agriculture, scientific research and countless other areas [4]. Diversity of ethno-medicinal plants and their usage in various local communities have been studied by various researchers [5-8]. Similarly, antimicrobial nature of plants is also studied by various researchers [9-11]. However, potential antimicrobial nature of the plants in an ecosystem against their indigenous microbes is not very much focused. By finding the efficiency of a plant in an ecosystem might explore the significance of the plant. These observations may also give clue to know the level of utilization or recovery of plants from its own ecosystem. The prime objective of the present study is to record the role of highly eco viable Fabaceae plants over the much variable bacterial population of a tropical freshwater lake. The present study was carried out in the Vellode Lake of Erode district, South India. It lies between $11^{\circ} 8^{\prime} 04.04^{\prime \prime} \mathrm{N}$ and $77^{0} 3752.42^{\prime \prime} E$ with the elevation of $764 \mathrm{ft}$. High summer temperature and heavy monsoon rainfall of the lake express its typical tropical climatic nature.

\section{Materials and Methods}

\subsection{Collection and Identification of Plants}

In the present study, whole or plant portions (leaves, flowers and fruits) of Fabaceae plant species were collected and preserved by pressing and drying method. All collected plant species were identified by the assistance of Botanical Survey of India (BSI) Southern Zone, Coimbatore.

\subsection{Extraction from Plants}

The collected leaves, flowers, bark and fruits of a species were shadow dried and powdered. The powdered plant portions of all the plant species were stored at room temperature in separate labeled air tight glass bottles. With proper homogenization, maceration, decoction and serial exhaustive extraction methods concentrated extracts with all bioactive compounds were obtained. Quantitative analysis was conducted to determine the phytochemical composition of the plants.

*Author for correspondence 


\subsection{Estimation of Phytochemicals}

The quantity of alkaloids, saponins and total phenols were determined by using Harborne methods [12]. Okeke and Elekwa (2003) method was used for tannin determination [13]. The mineral elements such as calcium, phosphorus, magnesium, potassium and nitrogen were determined using wet digestion extraction methods as described by Owjuwala [14], Andrew [15] and Nivozamsky et al., [16].

\subsection{Collection of Water and Sediment Samples}

For the isolation of indigenous bacterial species, water and sediment samples were collected in separate, sterilized container and with proper labeling, they were transported to the laboratory and stored in refrigerator at $4^{0} \mathrm{C}$ until further process. Basic parameters including $\mathrm{pH}$, total nitrogen, total phosphates, total potassium, calcium and magnesium were analyzed.

\subsection{Isolation and Identification of Bacterial Species}

By serial dilution method, water and soil samples were diluted to $10^{-1}, 10^{-2}, 10^{-3}, 10^{-4}$ and $10^{-5}$ concentrations. All diluted samples were poured in separate petri-dishes containing enough amount of nutrient agar medium (peptone: $5.0 \mathrm{~g}$, beef extract: $3.0 \mathrm{~g}, \mathrm{NaCl}: 5.0 \mathrm{~g}$, Agar: $15.0 \mathrm{~g}$ and distilled water: $1000 \mathrm{ml}$ ).

All poured plates were inverted and kept in incubator for 24 hours at $35^{\circ} \mathrm{C}-37^{\circ} \mathrm{C}$. Based on the color and morphology, the grown colonies were counted with the assistance of a colony counter. The top three dominant bacterial isolates from water and soil were selected for further identification tests. The isolates of water samples were named as WB1, WB2 and WB3. Similarly, isolates of soil as named SB1, SB2 and SB3. By continuous streaking method, the dominant three bacterial species of water and soil were sub-cultured to obtain pure isolates for further identification tests.

Identification of the bacterial isolates up to genus level was done on the basis of morphological and biochemical tests of Bergey's Manual [17].

\subsection{Antibacterial Activity}

Isolated indigenous bacterial species were properly inoculated and used for the assessment of antimicrobial activity. The antibacterial tests were done by following the disc diffusion method. $10 \mu \mathrm{l}$ of test microorganisms were seeded into respective petri plates with agar medium. The paper discs (5mm in diameter) were impregnated in solidified medium after dipping in extracts of fabaceae plants. After 24 hours of incubation period, the inhibition zones of the discs were measured. By comparing with inhibition zone of control, the inhibition zones of extracts were calculated.

\section{Results}

\subsection{Fabaceae Plants Species}

In the present investigation totally, 11 fabaceae plants including 3 trees (Acacia nilotica, Pongamia pinnata and Sesbania grandiflora), 2 shrubs (Cajanas cajan and Cassia auriculata), 2 herbs (Tephrosia purpuria and Vigna mungo), 4 climbing herbs (Abrus precatorus, Clitoria ternatia, Crotalaria vercosa and Mimosa pudica) were selected (Table 1).

\subsection{Quantification of Phytochemicals}

The phytochemicals including alkaloids, flavonoids, tannins, saponins, and phenols were estimated and presented in Fig. 1. Mineral elements such as phosphorus, calcium, magnesium, potassium and nitrogen were determined and their compositions are represented in Fig. 2.

\subsection{Physico-chemical Analysis of Water and Soil Samples}

Water and soil samples collected from Vellode lake for the isolation bacterial species were subjected to physicochemical analysis. Parameters including $\mathrm{pH}$, total nitrogen total phosphorus, total potassium, calcium, magnesium and chlorides were estimated for both water and soil samples. $\mathrm{C} / \mathrm{N}$ ratio and $\mathrm{N} / \mathrm{P}$ ratio were calculated for soil samples only. Physicochemical characteristics of the water and soil samples of the lake were represented in Table 2.

\subsection{Isolation of Bacterial Species}

From the collected water and soil samples of the Vellode lake, dominant three bacterial isolates of pour plates were taken for further subculture. From those subcultures required amount of the slant cultures were obtained and utilized for further biochemical tests for the identification of the isolates. The results obtained in the biochemical tests are given in the Table 3. 
Table 1. Fabaceae family plants of vellode lake

\begin{tabular}{|c|c|c|c|}
\hline $\begin{array}{c}\text { S. } \\
\text { N. }\end{array}$ & Species Name & $\begin{array}{c}\text { Common } \\
\text { Name }\end{array}$ & $\begin{array}{c}\text { Vernacular } \\
\text { Name }\end{array}$ \\
\hline 1 & Abrus precatorus & Crab's eye & Gundumani \\
\hline 2 & Acacia nilotica & $\begin{array}{c}\text { Gum Arabic } \\
\text { tree }\end{array}$ & Karuvallam \\
\hline 3 & Cajanas cajan & Pigeon Pea & Dhuarai \\
\hline 4 & Cassia auriculata & Tanner's cassia & Aavarai \\
\hline 5 & Clitoria ternatia & Butterfly pea & Sangu poo \\
\hline 6 & Crotalaria vercosa & Rattle pods & Vellai Avari \\
\hline 7 & Mimosa pudica & Shy plant & Tottachinughi \\
\hline 8 & Pongamia pinnata & Indian beech & Poovarasan \\
\hline 9 & Sesbania & Hummingbird & Agathi \\
\hline 10 & Tephrosia purpuria & Wild indigo & Kozlunghi \\
\hline 11 & Vigna mungo & Black gram & Ullundhu \\
\hline
\end{tabular}

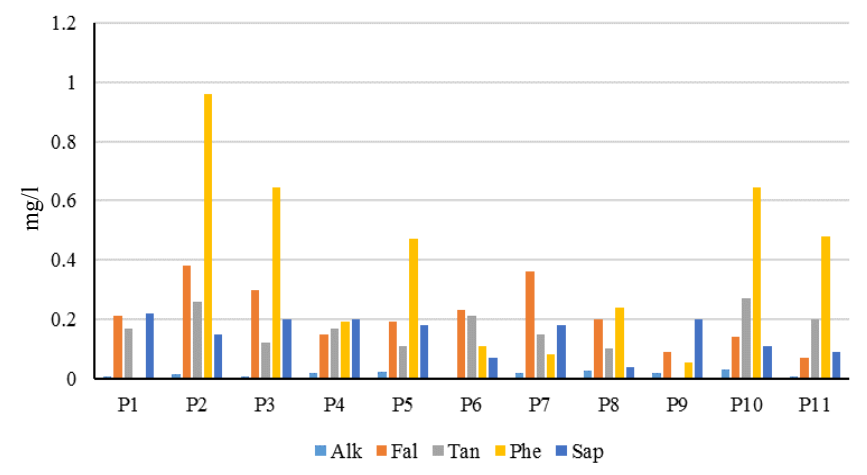

Fig. 1. Quantitative estimation of phytochemical contents of Fabaceae plants.

Table 2. Physicochemical analysis of water and soil samples of vellode lake

\begin{tabular}{|c|c|c|c|}
\hline S.N. & Parameters & Water & Soil \\
\hline 1 & $\mathrm{pH}$ & $6.82 \pm 0.3$ & $8.03 \pm 1.2$ \\
\hline 2 & Total Nitrogen & $11.45 \pm 2.2 \mathrm{mg} / \mathrm{l}$ & $0.192 \mathrm{mg} / \mathrm{kg}$ \\
\hline 3 & Total Phosphates & $0.13 \pm 0.35 \mathrm{mg} / \mathrm{l}$ & $0.04 \pm 0.01 \%$ \\
\hline 4 & Total Potassium & $34.46 \pm 1.7 \mathrm{mg} / \mathrm{l}$ & $192 \pm 23 \%$ \\
\hline 5 & C: N ratio & NA & $12.74 \pm 2.1 \%$ \\
\hline 6 & N: P ratio & NA & $4.29 \pm 1.8 \%$ \\
\hline 7 & Calcium & $29 \pm 1.76 \mathrm{mg} / \mathrm{l}$ & $46 \pm 4 \mathrm{mg} / \mathrm{kg}$ \\
\hline 8 & Magnesium & $7.89 \pm 0.91 \mathrm{mg} / \mathrm{l}$ & $16.2 \pm 0.9 \mathrm{mg} / \mathrm{kg}$ \\
\hline 9 & Chlorides & $72.7 \pm 1.38 \mathrm{mg} / \mathrm{l}$ & $40.8 \pm 3 \mathrm{mg} / \mathrm{kg}$ \\
\hline
\end{tabular}

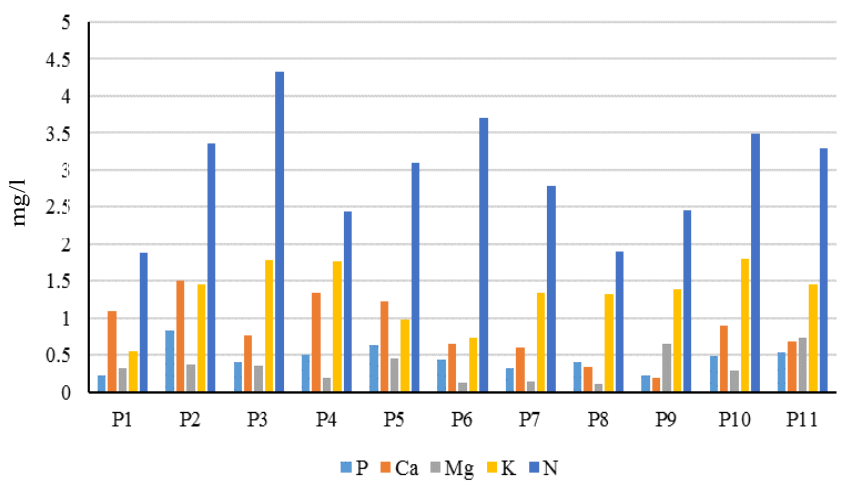

Fig. 2. Quantitative estimation of mineral elements of Fabaceae plants.

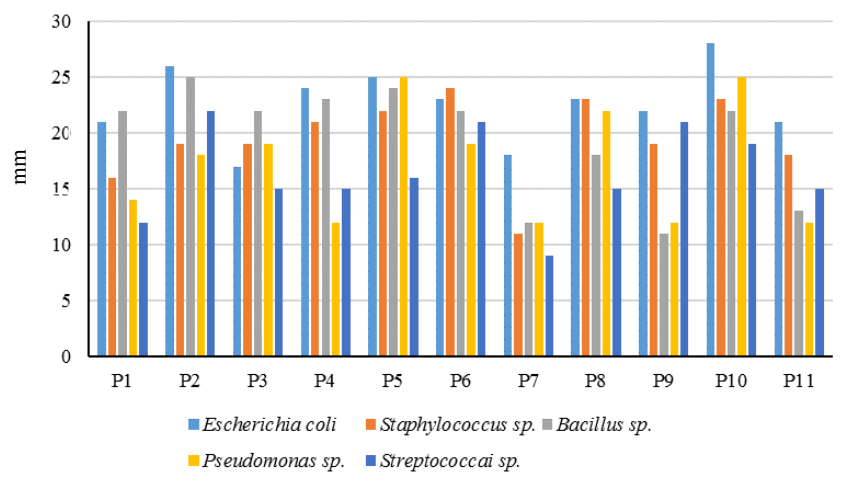

Fig. 3. Antibacterial activity (zone of inhibition in $\mathrm{mm}$ ) of Fabaceae plants against bacterial isolates from water and soil samples of Vellode lake.

From the water samples WB1 (E. coli), WB2 (Staphylococcus sp.) and WB3 (Bacillus sp.), from soil samples SB1 (Pseudomonas sp.), SB2 (Bacillus sp.) and SB3 (Streptococcai sp.) were isolated. Bacillus sp. of both water and soil samples were similar in morphology and in other biochemical tests.

\subsection{Antibacterial Activity}

Antibacterial activity of the 11 fabaceae plants of Vellode lake against the indigenous bacterial isolates of water and soil samples i.e Escherichia coli, staphylococcus sp., Bacillus sp., Pseudomonas sp. and Streptococcai sp. were observed in the form of zone of inhibition ( $\mathrm{mm}$ ) by the disc diffusion method in petri plates. The results obtained in the study were represented in Fig. 3.

\section{Discussion}

Inspite of favourable climate and soil quality the diversity of the fabaceae plants were very much limited due 
Table 3. Observation of biochemical tests for identification of bacterial isolates of water and soil samples of Vellode lake

\begin{tabular}{|c|c|c|c|c|c|c|c|}
\hline \multirow{2}{*}{ S. N. } & \multirow{2}{*}{ Tests } & \multicolumn{3}{|c|}{ Water } & \multicolumn{3}{|c|}{ Soil } \\
\hline & & WB1 & WB2 & WB3 & SB1 & SB2 & SB3 \\
\hline 1 & Colony colour & Yellowish & Creamy & Grayish & Light yellow & Grayish & White mucoid \\
\hline 2 & Colony appearance & Rough & Raised \&Smooth & Small round & Slightly raised & Small round & Rough \\
\hline 3 & Motility test & + & - & + & + & + & - \\
\hline 4 & Gram staining & - & + & + & - & + & + \\
\hline 5 & Catalase test & + & + & + & + & + & - \\
\hline 6 & Oxidase test & - & - & + & + & + & - \\
\hline 7 & Indole test & + & - & - & - & - & - \\
\hline 8 & Citrate test & + & + & - & + & - & + \\
\hline 9 & Methylred test & + & - & + & - & + & - \\
\hline 10 & Urease test & - & + & - & - & - & - \\
\hline 11 & $\mathrm{H}_{2} \mathrm{~S}$ test & - & - & - & - & - & - \\
\hline 12 & Voges-Proskauer test & - & - & - & - & - & - \\
\hline 13 & Nitrate reduction test & - & + & + & + & + & - \\
\hline \multicolumn{2}{|c|}{ Suspected bacterial species } & E. coli & Staphylo coccus sp. & Bacillus sp. & Pseudo monas sp. & Bacillus sp. & $\begin{array}{c}\text { Strepto coccai } \\
\text { sp. }\end{array}$ \\
\hline
\end{tabular}

Note: + indicates positive result; - indicates negative result

to strong competition from the invasive plants [18]. Quantification of phyto-components among the Fabaceae plants indicates variable nature of phytochemical composition of family of plants. These composition also indicates the uniqueness among the closely related plants of a family [19]. However, it is suggested that further investigation on the phytochemical composition can widen the differentiations among the plants of this family.

Physicochemical analysis of water and soil samples suggested that the conditions of the lake are very much suitable for the wide range of microbial (bacterial, algal and fungal) populations. Especially, $\mathrm{pH}$, total nitrogen of water samples and C:N ratio, $\mathrm{N}: \mathrm{P}$ ratio of the soil samples revealed the availability of different kinds of micro climates for varied kind of microbial populations. However, competitive nature of similar niche groups and temporal variations might give the dominance to some bacterial species $[20,21]$.

Antibacterial test results demonstrated the high efficacy of the all the plants against E.coli and least efficacy with Streptococcai sp. where, the plants have highly diverse range of inhibition rate against the remaining isolates. In fact, each plants species showed different magnitude inhibition with every isolates. Thus, the present investigation showed the highly varied range of characteristics among the plants of a family which indicates the importance of a particular species in its own habit. It is strongly recommended that the immediate actions to remove the invasive plants esp. Prosofis julifora and Parthenium sp. of this lake ecosystem, due to their strong competition behavior (in seed dispersal, light, water and nutrition) with native fabaceae and other family plants also [22]. Because, in an ecosystem there will be no compensation for loss of a species or loss of its abundance.

\section{References}

1. Bosco F.G., Arumugam R., "Ethanobotany of irular tribes in redhills, Tamilnadu, India”, Asian Pacific J. Trop. Disease, p. S874-S877, 2012.

2. Jayanthi P., Sindhuja R., Rajendran A., "Diversity of medicinal plants in the Madukkarai Hills of Southern Western ghats", India. J. Biosci. Res., vol. 4(1), p. 21-25, 2013.

3. Yadav R.N.S., Agarwala M., "Phyto chemical analysis of some medicinal plants", J. Phytology, vol. 3(12), p. 10-14, 2011.

4. Vasu K., Goud J.V., Suryam A., Singara., Chary M.A., "Biomolecular and phytochemical analysis of three aquatic angiosperms", Afr. J. Micorbiol. Res, vol. 3(8), p. 418-421, 2009. 
5. Rameshkumar S., Ramakritinan C.M., "Floristic survey of traditional herbal plants for treatments of various diseases from coastal diversity in Pudukkottai District, Tamilnadu, India”, J. Coastal Life Medi., vol. 1(3), p. 225-232, 2013.

6. Senthilkumar M.S.S., Vaidyanathan D., Sivakumar D., Basha G. "Diversity of ethnomedicinal plants used by Malayali tribals in Yelagiri hills of Eastern ghats, Tamil nadu, India”, Asian J. Plant Sci. Res., vol. 4(1), p. 69-80, 2014.t

7. Murugeswaran R., Rajendran A., Venkatesan K., Thomas B., Aravindan V. "Potential plants for unani system of medicine from Western Ghats of Coimbatore district, Tamilnadu, India”, J. Sci., vol. 4(2), p. 106-112, 2014.

8. Senthil Kumar M.S.S., Vaidyanathan D., Sivakumar D., Basha G., "Diversity of ethnomedicinal plants used by Malayali tribals in Yelagiri hills of Eastern ghats, Tamil nadu, India", Asian J. Plant Sci. Res., vol. 4(1), p. 69-80, 2014.

9. Kavitha P.A., Kumar P., Murthy N.P., Gopinath S.M., "Methonalic extract of Acacia nilotica and antibacterial activity against hospital isolates of Bengaluru District", I. J. of Latest Res. in Sci. and Tech., vol. 2(1), p. 522-524, 2013.

10. Deshpande S.N., Kadam D.G., "Phyto-chemical analysis and antibacterial activity of Acacia nilotica against Streptococcus mutans", Intl. J. Pharm. Pharmal. Sci., vol. 5(1), p. 236-238, 2013.

11. Verma V., Kumar S.U., Kumar S.A., Suparna S., Brijendra S., Goyal P., Rahul S.I.J., Pharma. Res. Develop., vol. 4(3), p. 251-256, 2011.

12. Harbone J.B., "Phytochemical methods", Chapman and Hall Ltd., London, p. 111-113, 2001.
13. Okeke C.U., Elekwa I.Z., "Phytochemical study on the extracts of Gongronema latifoliuin (Asclaptiaceae)", J. Health Visual Stud., vol. 5, p. 47-55, 2003.

14. Ojuwale J.A., "Experimental procedure of analysis in the laboratory”, Oxford Univ. Press, Ibadan, p. 46-48.

15. Andrew O.C., Official method of analysis, "Association of Official Analytical Chemists”, 13th Edition. Washington D.C., p. 248-254, 1999.

16. Nivozamsky I., Reck V.I., Houba V.N., Van V.W., "Novel Digestion techniques for multiple element plant analysis", Common Soil Sci. Plant Anal., vol. 14, p. 239-248, 2007.

17. Bergey D.H., Breed R.S., Murray E.G.D., Hitchens A.P. "Bergey's Manual of Determinative Bacteriology", 5th Edition. The Williams and Wilkins Co., Baltimore, 1939.

18. Stefan C., The estimation of land favorability for different crops and calculation of land price in an agricultural region in Romania. $46^{\text {th }}$ Crotian and $6^{\text {th }}$ International Symposium on Agriculture, Opatijia, 14-18 Feb 2011, p. 281-284.

19. Tiwari P., Kumar B., Kaur M., Kaur G., Kaur H. "Phytochemical screening and Extraction: A Review", I. J. Pharamaceutica and Sciencia, vol. 1(1), p. 98-106.

20. Nagarajan K., Saravanaraja M. "Role of phosphates on algal blooming during the summer months in Vellode lake, Erode district, Tamilnadu, India”, I. J. Univ. Pharmacy Biosci., vol. III(I), p. 19-25, 2014.

21. Krishnamoorthy P.S., Nagarajan K., "Surface water bacteriology of river Cauvery with reference to fecal coliforms", $I$. J. Univ. Pharm. Biosci., vol. 2(4), p. 209-214, 2013.

22. Wilson I.R.U., Gairifo C., Gibson M.R., "Risk assessment, eradication and biological control: global efforts to limit Australian acacias invasions", Diversity and Distributions, vol. 17, p. 1030-1046, 2011. 